\title{
PROTEKTIVITAS BUDAYA LOKAL DALAM MENINGKATKAN KARAKTER PESERTA DIDIK DI SDN MULYOREJO 03 SILO JEMBER
}

\author{
Sinta Yulis Pratiwi \\ Institut Agama Islam Negeri (IAIN) Jember \\ sintayulispratiwi@gmail.com \\ Titi Andari Ratih \\ Institut Agama Islam Negeri (IAIN) Jember \\ andarigmail.com
}

\begin{abstract}
Baban Tengah Hamlet, Mulyorejo Village, Silo District is a unique village. However, in its uniqueness there are several problems. Seen in the educational aspect, elementary school institutions are very important because the first foundation of children is to become the nation's next generation. However, along with the development of the children experience moral degradation. As in Baban Tengah hamlet, there are minors who have committed criminal acts by drinking alcohol and smoking. This is of course a problem in the world of education. From this, it is necessary to preserve culture and habituation of positive activities in order to form and enhance student character with various formal, informal and non-formal learning processes. This research use desciptive qualitative approach. As for the collection of data and information in this study using observation techniques, interview documentation and triangulation. The results of this study indicate the concept of local traditions, the results of local traditions, supporting and inbibiting factors in improving the character of students.
\end{abstract}

\section{Keywords: Local Culture, Character, SDN Mulyorejo 03 Silo Jember}

\begin{abstract}
Abstrak
Dusun Baban Tengah Desa Mulyorejo Kecamatan Silo merupakan desa yang unik. namun di dalam keunikannya terdapat beberapa permasalahan.Terlihat pada aspek pendidikan, lembaga sekolah dasar menjadi sangat penting karena pondasi pertama anak menjadi generasi penerus bangsa. Akan tetapi seiring berkembangnya zaman anak mengalami degradasi moral. Seperti halnya di dusun Baban Tengah terdapat anak di bawah umur sudah melakukan tindakan kriminal dengan
\end{abstract}


meminum-minuman keras dan merokok. Hal ini tentu menjadi permasalahan dalam dunia pendidikan. Dari hal tersebut diperlukan pelestarian budaya dan pembiasaan aktivitas positif guna pembentukan dan meniingkatkan karakter siswa dengan berbagai proses pembelajaran formal, informal maupun non formal. Penelitian ini menggunakan pendekatan deskriptif kualitatif. Adapun dalam pengumpulan data dan informasi dalam penelitian ini menggunakan teknik observasi, wawancara dokumentasi dan triangulasi. Hasil penelitian ini menunjukkan konsep tradisi lokal, hasil tradisi lokal, faktor pendukung dan penghambat dalam meningkatkan karakter peserta didik.

\section{Kata Kunci : Budaya Lokal, Karakter, SDN Mulyorejo 03 Silo Jember}

\section{Pendahuluan}

Sebuah bangsa akan bermartabat dan dihormati bangsa bangsa lain ketika memiliki pegangan nilai dan mengamalkannya untuk membangun peradaban yang luhur. Nilai - nilai yang terdapat dalam sebuah masyarakat tidak tercipta seketika, melainkan melalui proses panjang pengalaman dan dialektika hingga menemukan karakter yang khas. Nilai itu kemudian terobjektivikasi dan hidup secara dinamis ke dalam tradisi, budaya, habitus, dan bahasa keseharian. Bahasa dan tutur dalam sebuah masyarakat menunjukkan identitas sosial dan kebudayaan mereka. Bagi masyarakat, sebuah identitas dapat dimaknai sebagai pintu gerbang untuk mengetahui latar belakang mereka dan juga bekal yang berharga untuk mengetahui jati diri.

Setiap negara mempunyai budaya tersendiri seperti halnya bangsa Indonesia mempunyai budaya disetiap daerahnya dalam Qu'ran surah al-Hujarat: 13 Allah SWT berfirman: 
Vol. 13, No. 2, Oktober 2020

p-ISSN:2086 -0749

e-ISSN:2654-4784

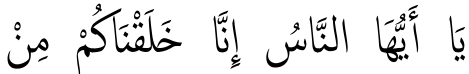

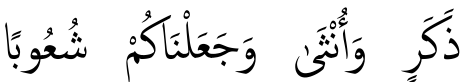

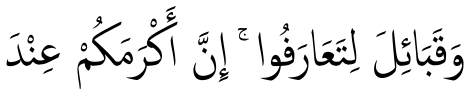

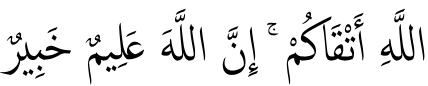
Artinya: "Hai manusia, sesunggubnya Kami menciptakan kamu dari seorang laki-laki dan seorang perempuan dan menjadikan kamu berbangsa-bangsa dan bersuku-suku supaya kamu saling mengenal. Sesunggubnya orang yang paling mulia di antara kamu di sisi Allab ialah orang yang paling bertakwa di antara kamu. Sesungsubnya Allab Maha Mengetabui lagi Maha Mengenal". (Qs. alHujurat: 13). ${ }^{1}$

Adat atau tradisi ketimuran bangsa Indonesia yang dikenal khas di dunia antara lain adalah sikap ramah, sopan, terbuka, menghargai sesama, semangat gotong royong tinggi, saling menghormati antar manusia dan

\footnotetext{
${ }^{1}$ Ihsan Muhammad, Aisyah Al-Qur'an dan Terjemah untuk Wanita (Bandung: Jabal Rodiyatul Jannah, 2010), 519.
}

agama. Akan tetapi keberlangsungan semangat ketimuran disaat ini agaknya seperti menemui jalan buntu karena disebabkan oleh perkembangan zaman.2 Masyarakat lokal sudah enggan menggunakan bahasa daerah ataupun tradisi khas daerahnya. Parahnya lagi sikap penolakan terhadap kearifan lokal tidak hanya ditampilkan dalam komunikasi dan tradisi khas daerah, tingkah laku mereka sudah keluar dari nilai - nilai lokal yang sarat akan ketimuran. Sendi - sendi kebudayaan bangsa ini mulai keropos. Diserang setiap waktu oleh kebudayaan global. Dampak dari itu sangat terasa ketika melihat sikap masyrakat yang kontra dengan nilai - nilai ketimuran.

\footnotetext{
2 Rohmatin Nazilah, Skripsi: Implementasi Kurikulum Muatan Lokal Bahasa Using dalam Membentuk Karakter Siswa SMPN 1 Giri Banyuwangi Jawa Timur, (Yogyakarta: UIN Sunan Kalijaga, 2014), 23.
} 


\section{Sinta Yulis Pratiwi, Titi Andari Ratih}

Di abad 21, globalisasi telah menjadi salah satu faktor paling berpengaruh terhadap perubahan dan pergeseran norma serta nilai budaya yang berlaku dalam tatanan sosial masyarakat. Perubahan tersebut telah Nampak jelas mempengaruhi cara pandang generasi muda sekarang terhadap norma -norma yang ada di daerah mereka. Produk norma dari masa lalu yang banyak memuat etika dan sopan santun, oleh mereka kini seringkali dipandang sebagai hal yang ribet dan tidak praktis. Anak - anak muda sekarang lebih suka menuruti budaya asing yang serba siap saji, dan akhirnya mereka pun keberatan menjalani sebuah proses yangdidalamnya tersirat banyak makna. Hal ini membuat mayoritas generasi muda mengalami krisis karakter.Mereka menjadi kerap menampilkan tingkah laku kurang santun dalam relasi sosial, baik dalam berperangai maupun berbahasa.
Dalam hal ini, pendidikan harusnya menjadi wadah yang mampu memperkenalkan anak dengan budaya atau tradisi lokal daerahnya. Maka dari itu, pentingnya mendidik siswa sesuai dengan tujuan pendidikan yakni Berdasarkan UU No. 2 Tahun 1985 yang berbunyi bahwa:

Tujuan pendidikan yaitu mencerdaskan kehidupan bangsa dan mengembangkan manusia yang seutuhnya yaitu yang beriman dan bertakwa kepada Tuhan Yang Maha Esa dan berbudi pekerti luhur, memiliki pengetahuan dan keterampilan, kesehatan jasmani dan rohani, kepribadian yang mantap dan mandiri serta rasa tanggung jawab kemasyarakatan bangsa. ${ }^{3}$

Namun faktanya, ada beberapa lembaga pendidikan yang tidak pro terhadap budaya atau tradisi lokal daerah yang ada. Lembaga pendidikan sebagai institusi yang tumbuh dan berkem-

\footnotetext{
${ }^{3}$ Sekertariat Negara RI 1945, UndangUndang Republik Indonesia Nomor 2 Tabun 1985.
} 
bang ditengah masyarakat sudah seharusnya kembali pada makna dasarnya, yakni membimbing secara sadar perkembangan jasmani dan rohani peserta didik menuju terbentuknya kepribadian mulia dengan berlandaskan pada ajaran Agama dan nilai-nilai keadaban yang dibentuk oleh kearifan lokal. Hal ini dikarenakan banyak praktisi pendidikan menganggap bahwa salah satu faktor mendasar dari fenomena dekadensi moral dan pudarnya kecintaan akan budaya atau tradisi lokal disbabkan oleh krisis karakter bangsa ini.4 Nilai-nilai kesantunan dan budi pekerti luhur yang diwariskan nenek moyang smakin ditinggalkan, bahkan menjadi asing di negeri sendiri.

Berbeda dengan lembaga pendidikan yang disebutkan diat-

\footnotetext{
${ }^{4}$ Rohmatin Nazilah, Skripsi: Implementasi Kurikulum Muatan Lokal, 24.
}

as, SDN Mulyorejo 03 sudah mampu menjadi wadah untuk memperkenalkan anak dengan budaya atau tradisi daerahnya. Dengan berbagai kenakalan anak dan degradasi moral yang sudah mewabah, SDN Mulyorejo 03 mampu memperbaiki karakter religius dan karakter cinta budaya dengan tradisi lokal khas daerah sebagai solusi utamanya.

Topik penelitian yang kami angkat atas dasar keprihatinan kami yang sudah melihat anak dibawah umur merokok dan minum-minuman keras yang bertempat di desa Mulyorejo yakni SDN Mulyorejo 03. Kami sempat melakukan wawancara kepada masyarakat sekitar sekolah bahwa ada beberapa siswa seusia SD yang sudah merokok dan minumminuman keras. Hal ini merupakan kenakalan anak yang tergo- 


\section{Sinta Yulis Pratiwi, Titi Andari Ratih}

long urgent di desa yang terletak disekitar perbukitan ini.

Dari berbagai lembaga pendidikan di dusun Baban Mulyorejo yang memiliki daya tarik paling kuat adalah SDN Mulyorejo 03 karena selain SD tersebut berstatus negeri juga banyak bantuan dari pemerintah mengingat tingkat perekonomian masyarakat sekitar yang masih relatif rendah. SDN Mulyorejo 03 mempunyai siswa yang cukup banyak yakni kurang lebih 200 yang terdiri dari desa Batu Ampar, Baban Atas, Baban Barat dan Baban Tengah yang notabene siswa berangkat dan pulang sekolah berjalan kaki, diantarkan orang tua dan bahkan naik sepeda motor, hal ini sudah menjadi kebiasaan mereka karena faktor jarak yang cukup jauh dari lembaga sehingga ketika hujan turun banyak yang terpeleset ketika naik sepeda motor sehingga fisik yang menjadi korban dan belajarpun terhambat seperti telat masuk sekolah dan sampai tidak sekolah. Selain itu, juga terdapat beberapa kasus kenakalan anak yang tergolong sangat vital, yakni merokok dan meminum minuman keras atau alkohol dengan berbagai campuran agar mereka mabuk. Hal tersebut ditanggapi oleh Bapak Sulaiman selaku guru kelas 5, sebagai bentuk perilaku anak SD yang menjadi peniru paling ulung.

SDN Mulyorejo 03 bekerja sama dengan masyarakat untuk turut melibatkan anak-anak dalam pelestarian tradisi lokal. Khususnya tradisi religius seperti perayaan sebagai wujud rasa syukur orang tua terhadap anak yang selesai mengaji iqro'.Sehingga anak-anak berlomba-lomba untuk menyelesaikan mengaji iqro' tersebut. Hal tersebut menyebabkan sedikit kemungkinan untuk anak mempunyai waktu mencoba-coba hal negatif yang akan menyebabkan terjadinya kenakalan anak dibawah umur, seperti merokok dan minum-minuman keras. Dengan demikian penelitian ten- 
Vol. 13, No. 2, Oktober 2020

p-ISSN:2086 -0749

e-ISSN:2654-4784

tang "Protektivitas Budaya Lokal dalam Meningkatkan Karakter

Peserta Didik di SDN Mulyorejo 03"perlu dilakukan untuk melestarikan budaya lokal dan meningkatkan karakter pesesrta didik di zaman sekarang yang sudah mengalami degradasi moral.

Dalam penelitian ini diharapkan mampu menjawab permasalahan mengenai: Bagaimana konsep protektifitas budaya lokal dalam meningkatkan karakter peserta didik, bagaimana hasil protektifitas budaya lokal dalam meningkatkan karakter peserta didik, apa saja faktor pendukung dan penghambat protektifitas budaya lokal dalam meningkatkan karakter peserta didik.

Metode yang digunakan dalam penelitian ini adalah kualitatif deskriptif dengan menggunakan teknik pengumpulan data observasi, wawancara, dokumentasi, triangulasi teknik dan sumber. Observasi yang dilakukan adalah observasi pasif yang mana peneliti tidak ikut terlibat dalam kegiatan hanya datang ditempat. Sedangkan wawancara yang digunakan adalah wawancara semi terstruktur dan tak berstruktur.

\section{Hasil Penelitian dan Pem-} bahasan

\section{Hasil Penelitian}

a. Konsep Tradisi Lokal dalam Meningkatkan Karakter Peserta Didik

Berdasarkan hasil wawancara kami kepada beberapa informan dan juga para pendidik, Dusun Baban Tengah beberapa tahun terakhir ini sedang mengalami krisis moral generasi mudanya. ${ }^{5}$ Tindakan kriminal seperti meminum minuman keras tidak

${ }^{5}$ Aqil, Wawancara, Jember, 4 Desember 2019 pukul 19.15 WIB 


\section{Sinta Yulis Pratiwi, Titi Andari Ratih}

lagi hanya dilakukan oleh orang dewasa namun anak-anak dibawah umur juga menjadi penikmatnya. Bukan hanya itu, anak-anak dibawah umur yang merokok pun sudah menjadi hal biasa. ${ }^{6}$ Anak dibawah umur memanglah pencontoh paling ulung.Maka dari itu, lingkungan keluarga dan lingkungan masyarakat haruslah mampu mendukung tumbuh kembang anak dengan menampilkan contoh atau tauladan yang baik.Tetapi realitanya, lingkungan beserta oknum-oknumnya masih belum mampu menjadi role mode bagi generasi selanjutnya.Sehingga hal tersebut menjadi keresahan tersendiri bagi para orang tua. Orang tua sangat mengharapkan hadirnya lembaga pendidikan formal maupun non formal yang mampu mem back up tumbuh kembang.

Saat peneliti berkunjung ke salah satu warga yakni Maryati

\footnotetext{
${ }^{6}$ Sulaiman, Wawancara, Jember, 4 Desember 2019 pukul 09.30 WIB
}

yang berusia 50 tahun, beliau menyambut dengan ramah kehadiran kami. Beliau sedikit menceritakan tentang kondisi keluarganya sekaligus putranya yang menikah di usia dini. Beliau mengatakan tidak tahu menahu banyak tentang pendidikan di Dusun Baban Tengah, yang beliau tahu hanya anak-anak yang baik dan memiliki sopan santun bersekolah di SD Mulyorejo 03.Sekolah Mulyorejo 03 sudah puluhan tahun berdiri, dan hingga saat ini masih memiliki daya tarik yang kuat juga menjadi kepercayaan banyak masyarakat Dusun Baban tengah dan sekitarnya. Menurut Maryati, SDN Mulyorejo 03 memiliki guru-guru yang ramah dan anak-anak yang penurut. ${ }^{7}$ Sama halnya dengan Maryati, santi yang berumur 55 tahun juga menyatakan pendapat yang tidak jauh berbeda.Santi menyatakan bahwa anak-anak

${ }^{7}$ Maryati, Wawancara, Jember, 4 Desember 2019 pukul 07.00 WIB 
Vol. 13, No. 2, Oktober 2020

p-ISSN:2086 -0749

e-ISSN:2654-4784

yang bersekolah di SDN Mulyorejo 03 tidak ada yang suka mabuk-mabukan dan jarang yang merokok. ${ }^{8}$ Nak kanak ekaantoh bhing seongguknah tadek se ler meller, keng ye terpengaruh ruah ka ded ngudeden se pleman alakoh deri Belih' (anak-anak disini nak sebenarnya tidak ada yang nakal, hanya saja terpengaruh dengan anak-anak muda yang kerja di Bali). ${ }^{9}$ Setelah itu Santi juga menyebutkan bahwa dengan orang tua memasukkan anakanya ke lembaga pendidikan formal maupun non formal, hal tersebut sangat berpengaruh pada perubahan karakter anaknya menjadi lebih baik."Warga kaantoh bennyak se nyekolaagih anaken ning SDN Mulyorejo gruah bhing.Selain begus, sekolaan jieh negeri bhing.Deddih anaken war-

${ }^{8}$ Santi, Wawancara, Jember, 4 Desember 2019 pukul 07.30 WIB

${ }^{9}$ Santi, Wawancara. ga tak mampu pagghun bisa sekola polanah olle bantuan derih pemerintah' (warga disini banyak yang menyekolahkan anaknya di SDN Mulyorejo itu nak.Selain karena sekolahnya bagus, sekolahitu juga negeri. Jadi anak dari warga yang tidak mampu bisa tetap bersekolah dengan bantuan dana dari pemerintah).

Setelah melakukan wawancara kepada masyarakat sekitar, dan berdasarkan hasil dari wawancara yang banyak menyatakan bahwa sekolah yang berpengaruh dalam pembentukan karakter anak-anak dusun Baban tengah adalah SDN Mulyorejo 03. Maka kami peneliti langsung mendatangi sekolah tersebut dan meminta salah satu guru untuk menjadi narasumber dalam pencarian data kami.Kami bertemu dengan Sulaiman yang berusia 49 tahun dan merupakan guru kelas 5 


\section{Sinta Yulis Pratiwi, Titi Andari Ratih}

di SDN Mulyorejo 03.Beliau menyatakan bahwa sekolah tersebut masih menjadi daya tarik hingga saat ini salah satu penyebabnya karena bukti out put atau lulusan yang berkualitas dan cukup menjanjikan. ${ }^{10}$ Anak-anak disini selain belajar mata pelajaran yang ada dalam pembelajaran di kelas, mereka juga ditanamkan nilai-nilai moral dan sopan santun khas daerahnya.Penanaman nilai dan karakter tersebut selain dilakukan dalam pembelajaran, juga ditanamkan pada tradisi atau budaya khas daerah.Jadi terdapat sinergitas antara lembaga sekolah dengan warga dalam melibatkan anak disetiap pelaksaan budaya atau tradisi lokal sekitar. Dalam hal ini, pelaksanaan budaya lokal ialah perayaan atau 'slametan' untuk anak yang sudah menyelesaikan mengaji iqro' yang kemudian akan berlanjut pada tahapan mengaji Al-Qur'an. Per-

\footnotetext{
10Sulaiman, Wawancara, Jember, 4 Desember 2019 pukul 09.30
}

ayaan tersebut dilaksanakan dengan maksud sebagai ungkapan rasa syukur orang tua karena anaknya telah menyelesaikan tahapan mengaji iqro'Selain itu, tradisi atau budaya ngajih langgerjuga sangat kental di dusun ini.Keduanya bertujuan untuk meningkatkan karakter religius peserta didik.Dalam pembelajaran sendiri terhadap mata pelajaran muatan lokal Bahasa Madura dan tarian khas daerah yang dapat menumbuhkan karakter cinta budaya peserta didik. ${ }^{11}$

Budaya lokal Dusun Baban Tengah berupa tradisi 'slametan' yang sampai saat ini terus dilestarikan.Pelaksanaan tradisi rutinan tersebut dilakukan setiap ada anak yang baru menyelesaikan ngaji iqro'nya.Hasil wawancara dengan Ahdil Umamiyah umur 30 Tahun: Sinergitas antara lembaga pendidikan SD Mulyorejo 03 dengan masyarakat demi tujuan meningkatkan karakter religius

\footnotetext{
${ }^{11}$ Sulaiman, Wawancara.
} 
Vol. 13, No. 2, Oktober 2020

p-ISSN:2086 -0749

e-ISSN:2654-4784

peserta didik, salah satunya dibangun bersama di TPQ AlIstidadul Akhiroh melalui diniyah dan kegiatan mengaji setiap setelah dhuhur hingga larut malam. Penanaman nilai-nilai Islami yang menngimplementasian akhlakul karimah dan beberapa referensi kitab seperti aqidatul awam dan Fathul Qorib selama proses diniyah tentunya sangat efektif dalam peningkatan karakter religius peserta didik. ${ }^{12}$ Selain itu, kegiatan mengaji iqro' membuat anak terus termotivasi dalam menyelesaikan 'ngajinya' hingga tahap Al-Qur'an. Motivasi tersebut berupa pemberian reward atau apresiasi terhadap anak yang baru menyelesaikan 'ngaji' iqro'nya. Reward tersebut berupa perayaan atau tasyakuran dengan pemberian makanan kepada warga sebagai

\footnotetext{
${ }^{12}$ Ahdil Umamiya, Wawancara, Jember, 5 Desember 2019 pukul 10.00
}

wujud rasa syukur orang tua terhadap anaknya karena sudah menyelesaikan 'ngaji' iqro'. Dari hal tersebut akhirnya anak berlombalomba untuk menyelesaikan 'ngajinya' agar bisa seperti temanteman lainnya yang sudah dirayakan dan 'dislameti'. Tidak hanya sekedar mengaji biasa, anak-anak di daerah Baban tengah ini dibiasakan unuk menghafal Qur'an. Untuk pemula, anak-anak banyak yang sudah menyelesaikan hafalan juz 30. Dan bagi tingkat atas, ada yang sudah mencapai hafalan 5 juz. Setelah mereka menyelesaikan hafalan minimal juz 30, maka anak-anak akan diwisuda dan didemonstrasikan hafalannya dihadapan orang tua dan masyarakat. Hal tersebut tentunya menumbuhkan semangat untuk anakanak lainnya agar mampu mencapai tingkat hafalan yang sama 


\section{Sinta Yulis Pratiwi, Titi Andari Ratih}

dan bisa segera menjadi peserta wisuda.

b. Hasil dari Tradisi Lokal

yang Dapat Meningkatkan

Karakter Peserta Didik

Budaya lokal Dusun Baban

Tengah berupa tradisi 'slametan' yang sampai saat ini terus dilestarikan.Pelaksanaan tradisi rutinan tersebut dilakukan setiap ada anak yang baru menyelesaikan ngaji iqro'nya. Hasil wawancara dengan Ahdil Umamiyah umur 30 Tahun: Sinergitas antara lembaga pendidikan SD Mulyorejo 03 dengan masyarakat demi tujuan meningkatkan karakter religius peserta didik, salah satunya dibangun bersama di TPQ AlIstidadul Akhiroh melalui diniyah dan kegiatan mengaji setiap setelah dhuhur hingga larut malam. Penanaman nilai-nilai Islami yang menngimplementasian akhlakul karimah dan beberapa referensi kitab seperti aqidatul awam dan Fathul Qorib selama proses diniyah tentunya sangat efektif dalam peningkatan karakter religius peserta didik. ${ }^{13}$

Selain itu, kegiatan mengaji iqro' membuat anak terus termotivasi dalam menyelesaikan 'ngajinya' hingga tahap Al-Qur'an. Motivasi tersebut berupa pemberian reward atau apresiasi terhadap anak yang baru menyelesaikan 'ngaji' iqro'nya. Reward tersebut berupa perayaan atau tasyakuran dengan pemberian makanan kepada warga sebagai wujud rasa syukur orang tua terhadap anaknya karena sudah menyelesaikan 'ngaji' iqro'. Dari hal tersebut akhirnya anak berlombalomba untuk menyelesaikan 'ngajinya' agar bisa seperti temanteman lainnya yang sudah dirayakan dan 'dislameti'. Tidak hanya sekedar mengaji biasa, anak-anak di daerah Baban tengah ini dibiasakan unuk menghafal Qur'an. Untuk pemula, anak-anak banyak yang sudah menyelesaikan hafalan juz 30. Dan bagi tingkat

${ }^{13}$ Ahdil Umamiya, Wawancara. 
Vol. 13, No. 2, Oktober 2020

p-ISSN:2086 -0749

e-ISSN:2654-4784

atas, ada yang sudah mencapai hafalan 5 juz. Setelah mereka menyelesaikan hafalan minimal juz 30, maka anak-anak akan diwisuda dan didemonstrasikan hafalannya dihadapan orang tua dan masyarakat. Hal tersebut tentunya menumbuhkan semangat untuk anakanak lainnya agar mampu mencapai tingkat hafalan yang sama dan bisa segera menjadi peserta wisuda.

Hal diatas tersebut tentunya sangat bermanfaat bagi anak dan dapat meningkatkan karakterreligius anak. Anak memiliki kesibukan lain diluar sekolah yang dapat mengisi waktu kosongnya sehingga tidak akan dimanfaatkan untuk hal-hal yang tidak berguna. Karena anak memiliki kesibukan lain, tentunya hal tersebut efektif membuat anak tidak mencoba halhal negatif yang dapat merusak dirinya. Karena ia sudah terlalu disibukkan oleh kegiatan-kegiatan positif setiap harinya.

c. Faktor Pendukung dan

Penghambat Tradisi Lokal

dalam Meningkatkan Karak-

ter Peserta Didik

Faktor pendukung dalam pelaksanaan tradisi atau budaya lokal di dusun Baban Tengah ini, karena dusun ini merupakan paku bumi tradisi-tradisi agama yang mengakar kuat pada diri masyarakatnya. Anak-anak sejak usia dini sudah mengaji di langgar-langgar sekitar dan mendapat pelajaran nilai-nilai agama yang jarang didapat disekolah-sekolah. Hal tersebut tentunya memudahkan sekolah untuk menanamkan nilainilai karakter religius kepada peserta didiknya.

Selain banyak faktor pendukung dalam pelaksanaan tradisi lokal di dusun ini, juga terdapat beberapa faktor penghambat.Salah 


\section{Sinta Yulis Pratiwi, Titi Andari Ratih}

satunya yakni, pengaruh lingkungan yang kurang baik.Disebutkan oleh Sulaiman salah satu guru SDN Mulyorejo 03, bahwa banyak anak-anak SD yang berperilaku negatif sebab terpengaruh oleh orang dewasa. ${ }^{14}$ Anak merupakan pencontoh paling ulung, jadi ia mudah sekali untuk mencontoh orang-orang disekitarnya tanpa menyaring atau memfilter terlebih dahulu. Hal tersebut merupakan faktor penghambat yang sulit untuk dicegah oleh pihak sekolah. Karena pihak sekolah tidak bisa selama 24 jam penuh mengawal dan mengawasi peserta didik.

\section{Pembahasan}

a. Konsep Budaya Lokal dalam Meningkatkan Karakter

Peserta Didik

Tindakan kriminal seperti meminum minuman keras tidak lagi hanya dilakukan oleh orang dewasa namun anak-anak dibawah umur juga menjadi penikmatnya.

${ }^{14}$ Sulaiman, Wawancara.
Bukan hanya itu, anak-anak dibawah umur yang merokok pun sudah menjadi hal biasa. ${ }^{15}$ Anak dibawah umur memanglah pencontoh paling ulung. Maka dari itu, lingkungan keluarga dan lingkungan masyarakat haruslah mampu mendukung tumbuh kembang anak dengan menampilkan contoh atau tauladan yang baik. Tetapi realitanya, lingkungan beserta oknum-oknumnya masih belum mampu menjadi role mode bagi generasi selanjutnya.Sehingga hal tersebut menjadi keresahan tersendiri bagi para orang tua. Orang tua sangat mengharapkan hadirnya lembaga pendidikan formal maupun non formal yang mampu mem back up tumbuh kembang.

Setelah melakukan wawancara kepada masyarakat sekitar, dan berdasarkan hasil dari wawancara yang banyak menyatakan bahwa sekolah yang ber-

\footnotetext{
${ }^{15}$ Sulaiman, Wawancara, Jember, 4 Desember 2019 pukul 09.30 WIB
} 
Vol. 13, No. 2, Oktober 2020

p-ISSN:2086 -0749

e-ISSN:2654-4784

pengaruh dalam pembentukan karakter anak-anak dusun Baban tengah adalah SDN Mulyorejo 03. Maka kami peneliti langsung mendatangi sekolah tersebut dan meminta salah satu guru untuk menjadi narasumber dalam pencarian data kami. Kami bertemu dengan Sulaiman yang berusia 49 tahun dan merupakan guru kelas 5 di SDN Mulyorejo 03. Beliau menyatakan bahwa sekolah tersebut masih menjadi daya tarik hingga saat ini salah satu penyebabnya karena bukti out put atau lulusan yang berkualitas dan cukup menjanjikan. ${ }^{16}$

Anak-anak di SDN Mulyorejo 03 selain belajar mata pelajaran yang ada dalam pembelajaran di kelas, mereka juga ditanamkan nilai-nilai moral dan sopan santun khas daerahnya. Pe-

\footnotetext{
${ }^{16}$ Sulaiman, Wawancara, Jember, 4 Desember 2019 pukul 09.30
}

nanaman nilai dan karakter tersebut selain dilakukan dalam pembelajaran, juga ditanamkan pada tradisi atau budaya khas daerah. Jadi terdapat sinergitas antara lembaga sekolah dengan warga dalam melibatkan anak disetiap pelaksaan budaya atau tradisi lokal sekitar. Dalam hal ini, pelaksanaan budaya lokal ialah perayaan atau 'slametan' untuk anak yang sudah menyelesaikan mengaji iqro' yang kemudian akan berlanjut pada tahapan mengaji Al-Qur'an. Perayaan tersebut dilaksanakan dengan maksud sebagai ungkapan rasa syukur orang tua karena anaknya telah menyelesaikan tahapan mengaji iqro'Selain itu, tradisi atau budaya ngajih langger juga sangat kental di dusun ini. Keduanya bertujuan untuk meningkatkan karakter religius peserta didik. Dalam pembelajaran sendiri terhadap mata pelajaran 


\section{Sinta Yulis Pratiwi, Titi Andari Ratih}

muatan lokal Bahasa Madura dan tarian khas daerah yang dapat menumbuhkan karakter cinta budaya peserta didik. ${ }^{17}$ 'Slametan’ tersebut merupakan suatu tradisi lokal yang sudah menjadi budaya yang terdapat di dusun Baban Tengah.

Budaya adalah bentuk jamak dari kata budi dan daya yang berarti cinta, karsa, dan rasa. Kata budaya sebenarnya berasal dari Sanskerta budhayah yaitu bentuk jamak kata buddhi yang berarti budi atau akal. Dalam bahasa Inggris, kata budaya berasal dari kata culture, dalam bahasa Belanda diistilahkan dengan kata cultuur, dalam bahasa Latin, berasal dari kata colera. Berarti mengola, mengerjakan, menyuburkan, mengembangkan tanah (bertani). Substansi utama kebudayaan merupakan wujud abstrak dari segala macam ide dan gagasan manusia yang bermunculan di dalam masyarakat yang memberi jiwa kepada masyarakat itu sendiri,

${ }^{17}$ Sulaiman, Wawancara. baik dalam bentuk atau berupa sistem pengetahuan, nilai, pandangan hidup, kepercayaan, persepsi dan etos kebudayaan. ${ }^{18}$

Sedangkan lokal sama dengan artinya dengan daerah, daerah merupakan suatu tempat yang mempunyai batas wilayah yang sudah tercatat secara administratif di suatu negara dan didalamnya terdapat sekelompok masyarakat. Daerah mempunyai wewenang tersendiri. Jadi, dapat disimpulkan bahwa budaya daerah merupakan suatu warisan yang diaplikasikan disuatu daerah dari generasi ke generasi yang dilakukan secara terus menerus dan berkembang bersama kelompok masyarakat yang mempunyai norma dan nilai tersendiri di daerah tersebut yang sudah menjadi dasar pemikiran masyarakat tersebut.

1) Kesenian

${ }^{18}$ Elly M. Setiadi dkk, Imu Sosial dan Budaya Dasar, (Jakarta: Fajar Interpratama Offset, 2012), 27. 
Vol. 13, No. 2, Oktober 2020

p-ISSN:2086 -0749

e-ISSN:2654-4784

Disuatu daerah memiliki cara mewujudkan ekspresi seni yang cenderung dengan pola kehidupan berbeda-beda yang sesuai dengan budaya daerahnya. ${ }^{19}$ Misalnya seni tari lahbako dan tari semarak Jember yang menjadi icon tari khas Jember. Dalam kesenian sendiri terdapat beberapa unsur nilai yang berbeda-beda seperti gotong royong, religius dan kebersamaan. Sedangkan dalam pendidikan formal ada pelajaran muatan lokal yang mengenalkan kesenian di daerahnya, salah satunya kesenian tari. SDN Mulyorejo 03 meningkatkan keseniannya melalui latihan tari yang di demonstrasikan ketika lepas pisah siswa-siswi kelas 6.

19 M. Rizqon Al musafiri dkk, Potensi Kearifan Lokal Suku Using sebagai Sumber Belajar Geografi SMA di Kabupaten Banyuwangi, Ilmu Pendidikan, Volume 1 no. 10, Oktober: 2016, hal 2042
2) Sosial Budaya

Aktivitas sosial budaya berhubugan dengan pola pemukiman, terbentuknya desa, sistem kekebaratan dan aktivitas masyarakat yang sudah menjadi budaya. Kegiatan sosial budaya bermacam-macam mulai dari kegiatan religius, kegiatan hukum dan aturan moral yang dipakai pada masyarakat tersebut. ${ }^{20}$ Tradisi yang sudah menjadi budaya dalam masyarakat Mulyorejo adalah tasyakuran ketika selesai 'ngaji', banyak siswa siswi SDN Mulyorejo 03 yang ikut 'ngaji' di TPQ dan masyarakat ikut berpartisiasi.

Setelah melakukan wawancara kepada masyarakat sekitar, dan berdasarkan hasil dari wawancara yang banyak menyatakan bahwa sekolah yang ber-

\footnotetext{
20 M. Rizqon Al musafiri dkk, hal 2043.
} 


\section{Sinta Yulis Pratiwi, Titi Andari Ratih}

pengaruh dalam pembentukan karakter anak-anak dusun Baban tengah adalah SDN Mulyorejo 03. Lalu selain pendidikan formal ada pendidikan informal yang disebut dengan TPQ dengan tradisi atau budaya ngajih langger juga sangat kental di dusun ini. Keduanya bertujuan untuk meningkatkan karakter religius peserta didik.Dalam pembelajaran sendiri terhadap mata pelajaran muatan lokal Bahasa Madura dan tarian khas daerah yang dapat menumbuhkan karakter cinta budaya peserta didik. ${ }^{21}$

Karakter adalah bentuk watak, tabiat, akhlak yang melekat pada pribadi seseorang yang terbentuk dari hasil internalisasi yang digunakan sebagai landasan untuk berpikir dan berperilaku sehingga menimbulkan suatu ciri khas pada individu tersebut. Karakter individu akan berkembang dengan baik, apabila memperoleh pen-

${ }^{21}$ Sulaiman, Wawancara. guatan yang tepat, yaitu berupa pendidikan. ${ }^{22}$

Undang-Undang Republik Indonesia Nomor 20 Tahun 2003 tentang Sistem Pendidikan $\mathrm{Na}$ sional (Sisdiknas) telah merumuskan fungsi dan tujuan pendidikan nasional. Pasal 3 UU tersebut menyatakan :

Pendidikan nasional berfungsi mengembangkan kemampuan dan membentuk watak serta peradaban bangsa yang bermartabat dalam rangka mencerdaskan kehidupan bangsa, bertujuan untuk berkembangnya potensi peserta didik agar menjadi manusia yang beriman dan bertaqwa kepada Tuhan YME, berakhlak mulia, sehat, berilmu, cakap, mandiri, dan menjadi warga negara yang demokratis serta bertanggung jawab. ${ }^{23}$

Pasal tersebut merupakan dasar bagi pengembangan dan

\footnotetext{
${ }^{22}$ Binti Maunah, Implementasi Pendidikan Karakter dalam Pembentukan Kepribadian Holistik Siswa, Jurnal IAIN Tulungagung, (2015), 91

${ }^{23}$ Sekertariat Negara RI 1945, Undang-undang No. 20 Tahun 2003 Tentang Sistem Pendidikan Nasional
} 
pembentukan karakter manusia khususnya generasi muda. Pembinaan karakter manusia selaku generasi muda dapat ditempuh dengan berbagai upaya, termasuk melalui pendidikan yang dilakukan secara terprogram, bertahap, dan berkesinambungan. ${ }^{24}$

1) Nilai - nilai karakter

Karakter berasal dari nilai tentang sesuatu. Suatu karakter akan melekat dengan nilai dari perilaku seseorang. Karena itu, dalam perspektif karakter, tidak ada perilaku anak yang tidak bebas dari nilai. Sejak sebelum kemerdekaan hingga sekarang, Indonesia sudah mengupayakan terealisasinya nilai - nilai karakter bangsa yang dikristalkan dalam Pancasila dan dalam kehidupan sehari - hari. Nilai - nilai karakter yang dijiwai oleh sila - sila Pan-

\footnotetext{
${ }^{24}$ Binti Maunah, Implementasi Pendidikan Karakter, 92.
}

casila pada masing - masing bagian tersebut dapat dikemukakan sebagai berikut:

a) Karakter yang bersumber dari olah hati, antara lain: beriman dan bertaqwa, jujur, amanah, adil, tertib, taat aturan, bertanggung jawab, berempati, berani mengambil resiko danpantang menyerah.

b) Karakter yang bersumber dari olah pikir, antara lain: cerdas, kritis, kreatif, inovatif, ingin tahu, produktif, berorientasi kepada iptek, dan reflektif

c) Karakter yang bersumber dari olah raga/kinestetika, antara lain: bersih, sehat, sportif, tangguh, andal, berdaya tahan, bersahabat, kooperatif, determinative, kompetitif, ceria, dan gigih. 


\section{Sinta Yulis Pratiwi, Titi Andari Ratih}

d) Karakter yang bersumber dari olah rasa dan kersa, antara lain: kemanusiaan, saling menghargai, gotong royong, kebersamaan, ramah, hormat, toleran, nasionalis, peduli, kosmopolit (mendunia), mengutamakan kepentingan umum, dinamis, kerja keras, beretos kerja. ${ }^{25}$

2) Jenis - jenis karakter

Karakter yang menjadi acuan seperti yang terdapat dalam The Six Pillars of Character yang dikeluarkan oleh Character Counts! Coalition (a project of The Joseph Institute of Ethics). Enam jenis karakter yang dimaksud adalah sebagai berikut:

a) Trustworthiness, bentuk karakter yang membuat seseorang menjadi: berintegritas, jujur, dan loyal.

b) Fairness, bentuk karakter yang membuat seseorang memiliki

\footnotetext{
${ }^{25}$ Marzuki, Pendidikan Karakter Islam (Jakarta : Amzah, 2019), 43.
}

pemikiran terbuka serta tidak suka memanfaatkan orang lain.

c) Caring, bentuk karakter yang membuat seseorang memiliki sikap peduli dan perhatian terhadap orang lain maupun kondisi sosial lingkungan sekitar.

d) Respect, bentuk karakter yang membuat seseorang selalu menghargai dan menghormati orang lain.

e) Citizenship, bentuk karakter yang membuat seseorang sadar hukum dan peraturan serta peduli terhadap lingkungan alam.

f) Responsibility, bentuk karakter yang membuat seseorang bertanggung jawab, disiplin, dan selalu melakukan sesuatu dengan sebaik mungkin. ${ }^{26}$

\footnotetext{
${ }^{26}$ Wanda Chrisiana,Upaya Penerapan Pendidikan Karakter Bagi Mahasiswa (Studi Kasus di Jurusan Teknik Industri Uk Petra), Jurnal Teknik Industri, (2005), 76.
} 
Vol. 13, No. 2, Oktober 2020

p-ISSN:2086 -0749

e-ISSN:2654-4784

b. Hasil dari Budaya Lokal yang Dapat Meningkatkan

Karakter Peserta Didik

Hasil wawancara dengan Ahdil Umamiyah umur 30 Tahun: Sinergitas antara lembaga pendidikan SD Mulyorejo 03 dengan masyarakat demi tujuan meningkatkan karakter religius peserta didik, salah satunya dibangun bersama di TPQ Al-Istidadul Akhiroh melalui diniyah dan kegiatan mengaji setiap setelah dhuhur hingga larut malam. Penanaman nilai-nilai Islami yang menngimplementasian akhlakul karimah dan beberapa referensi kitab seperti aqidatul awam dan Fathul Qorib selama proses diniyah tentunya sangat efektif dalam peningkatan karakter religius peserta $\operatorname{didik}^{27}$

Hal diatas tersebut tentunya sangat bermanfaat bagi anak dan

\footnotetext{
${ }^{27}$ Ahdil Umamiya, $W$ awancara.
}

dapat meningkatkan karakterreligius anak. Anak memiliki kesibukan lain diluar sekolah yang dapat mengisi waktu kosongnya sehingga tidak akan dimanfaatkan untuk hal-hal yang tidak berguna. Karena anak memiliki kesibukan lain, tentunya hal tersebut efektif membuat anak tidak mencoba halhal negatif yang dapat merusak dirinya. Karena ia sudah terlalu disibukkan oleh kegiatan-kegiatan positif setiap harinya. Karakter religius disebut juga dengan karakter islami.

1) Pengertian karakter islami

Pendidikan karakter dalam Islam diartikan dengan pendidikan akhlak. Kata akhlak berasal dari Bahasa Arab, yakni jamak dari "kbuluqun" yang berarti budi pekerti, perangai, tingkah laku atau tabiat, tata krama, sopan santun, adab dan tindakan. Kata akhlak juga berasal dari kata 


\section{Sinta Yulis Pratiwi, Titi Andari Ratih}

khalaqa atau khalqun artinya kejadian, serta erat hubungannya dengan "khaliq" yang artinya menciptakan, tindakan atau perbuatan, sebagaimana terdapat kata al-khaliq yang artinya pencipta dan makhluq yang artinya yang diciptakan. Islami dalam Hasan Alwi artinya adalah bersifat keislaman, atau mengandung unsur-unsur serta nilai-nilai Islam. Karakter Islami sesungguhnya sudah diperintahkan oleh Allah, hal ini sebagaimana difirmankan Allah SWT dalam Qs. An Nahl ayat 90 sebagai berikut:

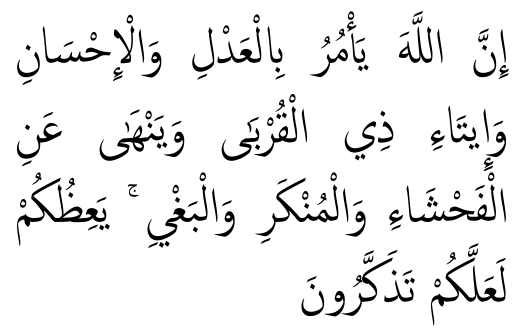

Artinya : "Sesunggubnya Allah menyuruh (kamu) berlaku adil dan berbuat kebajikan, memberi kepada kaum kerabat, dan Allab melarang dari perbuatan keji, kemungkaran dan permusuban. Dia memberi pengajaran kepadamu agar kamu dapat mengambil pelajaran." (Q.S An-Nabl: 90) ${ }^{28}$

Menjadikan pendidikan karakter Islam sudah ditanamkan oleh Allah dalam Al Qur'an. Islami menurut KBBI adalah bersifat keislaman, artinya menyandarkan segala sesuatu pada Islam yang berdasarkan pada Al Qur'an dan Al Hadits. Islami mempunyai maksud bahwa perbuatan maupun tindakan senantiasa berlandaskan pada prinsip-prinsip Islam. ${ }^{29}$

Berdasarkan pengertian di atas dapat disimpulkan bahwa karakter Islami adalah suatu tindakan atau perbuatan, perangai, tingkah laku dan tabiat yang berasaskan pada nilai-nilai Islam, sehingga pendidikan karakter Islami merupakan bentuk pendidikan dengan menanamkan sifatsifat keislaman sehingga dapat

\footnotetext{
${ }^{28}$ Tim Tashih Departemen Agama. 1995. Al Qur'an dan Tafsirnya Jilid VII. Medan: PT. Dana Bhakti Wakaf

${ }^{29}$ Pusat Bahasa DEPDIKNAS, Kamus Besar Bahasa Indonesia, (Jakarta: Balai Pustaka, 2008)
} 
Vol. 13, No. 2, Oktober 2020

p-ISSN:2086 -0749

e-ISSN:2654-4784

membentuk tindakan atau perbuatan yang sesuai dengan aturan Islam.

2) Macam - macam karakter islami

Banyak sekali macam karakter islami jika ditinjau dari berbagai aspek. Tetapi ada 4 karakter Islami yang paling fundamental dan wajib dimiliki peserta didik di abad 21 ini, yaitu:

\section{(a) Amanah}

Amanah adalah sikap yang dapat dipercaya dan dapat diandalkan dalam menjalankan komitmen, tugas, dan kewajiban. Amanah juga dipandang sebagai sikap jujur, tidak menipu atau mencuri, tangguh dalam melakukan apa yang dikatakan, memiliki keberanian untuk melakukan hal yang benar, membangun reputasi yang baik, dan setia pada keluarga teman, dan negara (Character Center). Dalam karakter amanah tekandung sikap kejujuran dan integritas

(b) Rasa Hormat

Rasa hormat (respect) merupakan cara merasakan dan berperilaku. Rasa hormat adalah suatu sikap penghargaan, kekaguman, atau penghormatan kepada pihak lain. Rasa hormat sangat penting dalam kehidupan sehari-hari. Anak-anak biasa diajarkan untuk menghormati orangtua, saudara, guru, orang dewasa, aturan sekolah, keluarga, peraturan lalulintas, dan budaya serta tradisi yang dianut dalam masyarakat. Rasa hormat itu harus dibangun dan dikembangkan melalui jalur pendidikan khususnya di dalam ruang kelas di samping diajarkan dalam lingkungan rumah tangga dan masyarakat. ${ }^{30}$

(c) Tanggung Jawab

${ }^{30}$ Marzuki, Pendidikan, 57. 


\section{Sinta Yulis Pratiwi, Titi Andari Ratih}

Tanggung jawab (responsibility) adalah suatu tugas atau kewajiban untuk melakukan atau menyelesaikan tugas dengan penuh kepuasan (yang diberikan oleh seseorang, atau atas janji atau komitmen sendiri) yang harus dipenuhi seseorang, dan yang memiliki konsekuen hukuman terhadap kegagalan. Bertanggung jawab berarti bertanggung jawab atas berbagai pilihan dalam menjalani kehidupan dengan damai, aman, dan sejahtera. Hal ini berarti bahwa kita bertanggung jawab terhadap apa yang kita pikirkan, rasakan, dan lakukan. ${ }^{31}$

(d) Adil

Adil merupakan suatu kata yang mudah diungkapkan namun sangat sulit untuk dilakukan. Kesulitannya karena melibatkan keadaan keikhlasan hati untuk membedakan antara kepentingan individu atau kelompok sendiri dan kepentingan individudan kelompok lain. Adil yang juga

${ }^{31}$ Marzuki, Pendidikan, 60. mempunyai pengertian menempatkan sesuatu pada tempatnya sesuai dengan porsi dan kapasitasnya dalam suatu hal. Keadilan memang sesuatu yang sangat dibutuhkan oleh semua orang, tanpa keadilan mustahil sesuatu dapat dibangun dengan baik. Keadilan dapat dilihat dari segi proses, kenetralan dan persamaan. ${ }^{32}$

c. Faktor Pendukung dan Penghambat Budaya Lokal dalam Meningkatkan Karakter Peserta Didik

Terdapat faktor pendukung dan penghambat dalam suatu lingkungan pendidikan dan lingkungan sosial. Anak-anak sejak usia dini sudah mengaji di langgarlanggar sekitar dan mendapat pelajaran nilai-nilai agama yang jarang didapat disekolah-sekolah. Hal tersebut tentunya memudahkan sekolah untuk menanamkan nilainilai karakter religius kepada peserta didiknya. Namun, juga ter-

\footnotetext{
54
} 
dapat penghambat Salah satunya yakni, pengaruh lingkungan yang kurang baik. Disebutkan oleh Sulaiman salah satu guru SDN Mulyorejo 03, bahwa banyak anak-anak SD yang berperilaku negatif sebab terpengaruh oleh orang dewasa. ${ }^{33}$

1) Nilai - nilai karakter

Karakter berasal dari nilai tentang sesuatu. Suatu karakter akan melekat dengan nilai dari perilaku seseorang. Karena itu, dalam perspektif karakter, tidak ada perilaku anak yang tidak bebas dari nilai. Sejak sebelum kemerdekaan hingga sekarang, Indonesia sudah mengupayakan terealisasinya nilai - nilai karakter bangsa yang dikristalkan dalam Pancasila dan dalam kehidupan sehari - hari. Nilai - nilai karakter yang dijiwai oleh sila - sila Pancasila pada masing - masing bagi-

\footnotetext{
${ }^{33}$ Sulaiman, Wawancara.
}

an tersebut dapat dikemukakan sebagai berikut:

a) Karakter yang bersumber dari olah hati, antara lain: beriman dan bertaqwa, jujur, amanah, adil, tertib, taat aturan, bertanggung jawab, berempati, berani mengambil resiko danpantang menyerah

b) Karakter yang bersumber dari olah pikir, antara lain: cerdas, kritis, kreatif, inovatif, ingin tahu, produktif, berorientasi kepada iptek, dan reflektif

c) Karakter yang bersumber dari olah raga/kinestetika, antara lain: bersih, sehat, sportif, tangguh, andal, berdaya tahan, bersahabat, kooperatif, determinative, kompetitif, ceria, dan gigih.

d) Karakter yang bersumber dari olah rasa dan kersa, antara lain: kemanusiaan, saling menghargai, gotong royong, kebersa- 


\section{Sinta Yulis Pratiwi, Titi Andari Ratih}

maan, ramah, hormat, toleran, nasionalis, peduli, kosmopolit (mendunia), mengutamakan kepentingan umum, dinamis, kerja keras, beretos kerja, ${ }^{34}$

\section{Simpulan}

SDN Mulyorejo 03 merupakan SD yang terletak di dusun Baban Tengah desa Mulyorejo kecamatan Silo Jember. Arus globalisasi sudah menjadikan Degradasi moral pada anak-anak desa Mulyorejo, sehingga pembelajaran karakter perlu ditingkatkan. Konsep protektifitas budaya lokal dalam meningkatkan karakter peserta didik di SDN Mulyorejo 03 yaitu belajar mata pelajaran yang ada dalam pembelajaran di kelas, mereka juga ditanamkan nilai-nilai moral dan sopan santun khas daerahnya. Penanaman nilai dan karakter tersebut selain dilakukan dalam pembelajaran, juga ditanamkan pada tradisi atau budaya khas daerah

${ }^{34}$ Marzuki, 43. terlebih pada pelajaran muatan lokal bahasa Madura dan tarian khas daerah yang dapat menumbuhkan karakter cinta budaya peserta didik.35 Jadi terdapat sinergitas antara lembaga sekolah dengan warga dalam melibatkan anak disetiap pelaksaan budaya atau tradisi lokal sekitar. Dalam hal ini, pelaksanaan budaya lokal ialah perayaan atau 'slametan' untuk anak yang sudah menyelesaikan mengaji iqro’.

Dalam meningkatkan karakter di TPQ Al-Istidadul Akhiroh melalui diniyah dan kegiatan mengaji. Penanaman nilai-nilai Islami yang mengimplementasian akhlakul karimah dan beberapa referensi kitab seperti aqidatul awam dan Fathul Qorib selama proses diniyah tentunya sangat efektif dalam peningkatan karakter religius peserta didik.36 Selain itu, kegiatan mengaji iqro' membuat anak terus termotivasi dalam me-

${ }^{35}$ Sulaiman, Wawancara.

${ }^{36}$ Ahdil Umamiya, Wawancara. 
nyelesaikan 'ngajinya' hingga tahap Al-Qur'an. Motivasi tersebut berupa pemberian reward atau apresiasi terhadap anak yang baru menyelesaikan 'ngaji' iqro'nya. Reward tersebut berupa perayaan atau tasyakuran dengan pemberian makanan kepada warga sebagai wujud rasa syukur orang tua terhadap anaknya karena sudah menyelesaikan 'ngaji' iqro'.

Adapun Faktor pendukung dalam pelaksanaan tradisi atau budaya lokal di dusun Baban Tengah ini. Anak-anak sejak usia dini sudah mengaji di langgar-langgar sekitar dan mendapat pelajaran nilai-nilai agama yang jarang didapat disekolah-sekolah. Hal tersebut tentunya memudahkan sekolah untuk menanamkan nilainilai karakter religius kepada peserta didiknya. Sedangkan faktor penghambatnya salah satunya yakni, pengaruh lingkungan yang kurang baik. Disebutkan oleh Sulaiman salah satu guru SDN Mulyorejo 03, bahwa banyak anak-anak SD yang berperilaku negatif sebab terpengaruh oleh orang dewasa.37 Anak merupakan pencontoh paling ulung, jadi ia mudah sekali untuk mencontoh orang-orang disekitarnya tanpa menyaring atau memfilter terlebih dahulu. Hal tersebut merupakan faktor penghambat yang sulit untuk dicegah oleh pihak sekolah. Karena pihak sekolah tidak bisa selama 24 jam penuh mengawal dan mengawasi peserta didik.

\section{Daftar Pustaka}

Al Musafiri, Rizqon, M dkk. 2016. Potensi Kearifan Lokal Suku Using sebagai Sumber Belajar Geografi SMA di Kabupaten Banyunangi. Ilmu Pendidikan. Volume 1 no. 10.

Aqil. 2019. Wawancara. Jember. pukul 19.15 WIB

${ }^{37}$ Sulaiman, Wawancara. 


\section{Sinta Yulis Pratiwi, Titi Andari Ratih}

Chrisiana, Wanda. 2005. Upaya Penerapan Pendidikan Karakter Bagi Mahasiswa (Studi Kasus di Jurusan Teknik Industri Uk Petra). Jurnal Teknik Industri.

Maunah, Binti. 2015. Implementasi Pendidikan Karakter dalam Pembentukan Kepribadian Holistik Siswa. Jurnal IAIN Tulungagung.

Maryati. 2019. Wawancara. Jember. pukul 07.00 WIB

Marzuki. 2019. Pendidikan Karakter Islam . Jakarta : Amzah

M. Elly, Setiadi dkk. 2012. Ilmu Sosial dan Budaya Dasar. Jakarta: Fajar Interpratama Offset.

Muhammad, Ihsan. 2010. Aisyah Al-Qur'an dan Terjemah untuk Wanita. Bandung: Jabal Rodiyatul Jannah.

Nazilah, Rohmatin. 2014. Skripsi: Implementasi Kurikulum Muatan Lokal Bahasa Using dalam Membentuke Karakter Siswa SMPN 1 Giri Banyuwangi Jawa Timur. Yogyakarta: UIN Sunan Kalijaga.

Santi. 2019. Wawancara, Jember. pukul 07.30 WIB
Sekertariat Negara RI 1945, Undang-undang No. 20 Tahun 2003 Tentang Sistem Pendidikan Nasional

Sekertariat Negara RI 1945, Undang-Undang Republike Indonesia Nomor 2 Tabun 1985.

Sulaiman. 2019. Wawancara. Jember. pukul 09.30 WIB

Pusat Bahasa DEPDIKNAS. 2008. Kamus Besar Bahasa Indonesia. Jakarta: Balai Pustaka.

Tim Tashih Departemen Agama. 1995. Al Qur'an dan Tafsirnya Jilid VII. Medan: PT. Dana Bhakti Wakaf

Umamiya, Ahdil. 2019. Wawancara. Jember. pukul 10.00 